\title{
Crustaceans from antipatharians on banks of the northwestern Gulf of Mexico
}

\author{
Mary K. Wicksten', Marissa F. Nuttall2, Emma L. Hickerson² \\ I Biology, Texas AđM University, College Station Texas U.S.A. 77843-3258 2 Flower Gardens Banks Natio- \\ nal Marine Sanctuary, 4700 Avenue U, Galveston, Texas 77551 U.S.A. \\ Corresponding author: Mary K. Wicksten (Wicksten@bio.tamu.edu)
}

Academic editor:I.S. Wehrtmann | Received 19September 2013|Accepted 13 January 2014| Published25 November 2014

http://zoobank.org/AFC34B87-FAED-44B8-BD24-14B0604259AB

Citation: Wicksten MK, Nuttall MF, Hickerson EL (2014) Crustaceans from antipatharians on banks of the northwestern Gulf of Mexico. In: Wehrtmann IS, Bauer RT (Eds) Proceedings of the Summer Meeting of the Crustacean Society and the Latin American Association of Carcinology, Costa Rica, July 2013. ZooKeys 457: 45-54. doi: 10.3897/zookeys.457.6280

\begin{abstract}
The stalked barnacle Oxynaspis gracilis, the chirostylid squat lobster Uroptychus sp., and the caridean shrimps Periclimenes cf. antipathophilus and Pseudopontonides principis have been collected at $68-124 \mathrm{~m}$ by a remotely operated vehicle (ROV) on banks in the northern Gulf of Mexico. These species inhabited six species of antipatharian hosts. Pseudopontonides principis, O. gracilis, and $U$. sp. were not confined to a single host species. Except for O. gracilis, collected by ROV in 2004-2005, these species have not been reported previously in the northwestern Gulf of Mexico.
\end{abstract}

\section{Keywords}

Anomura, Caridea, Cirripedia, Antipatharia, Gulf of Mexico

\section{Introduction}

Antipatharians (Cnidaria: Anthozoa: Hexacorallia), commonly called black corals or wire corals, tend to inhabit deeper reef areas or cliffs in the greater Caribbean-west Atlantic region (Fig. 1). In the Gulf of Mexico, they rarely inhabit depths that can be reached by SCUBA divers. Boland (2005) reported Plumapathes pennacea (Pallas) 
from four oil platforms at $9.5-43.0 \mathrm{~m}$ at the following locations: $28^{\circ} 00^{\prime} \mathrm{N}, 93^{\circ} 17^{\prime} \mathrm{W}$; $27^{\circ} 8^{\prime} \mathrm{N}, 93^{\circ} 40^{\prime} \mathrm{W} ; 27^{\circ} 46^{\prime} \mathrm{N}, 93^{\circ} 8^{\prime} \mathrm{W} ; 27^{\circ} 46^{\prime} \mathrm{N}, 93^{\circ} 19^{\prime} \mathrm{W}$; and at the East Flower Garden Bank buoy 6, $27^{\circ} 55^{\prime} \mathrm{N}, 93^{\circ} 36^{\prime} \mathrm{W}$. One of us (MW) saw (but did not collect or photograph) a "wire coral" (Stichopathes sp.) at a depth of $33 \mathrm{~m}$ on West Flower Gar-

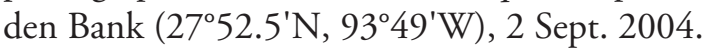

Black corals have been documented to host many associated species, including crustaceans, polychaetes, mollusks, ophiuroids, and fishes (Totton 1923, Warner 1981, Humes 1990, Grange 1991, Pettibone 1991, Glasby 1994, Wirtz and d'Udekemd'Acoz 2001, Castro et al. 2004, Molodtsova and Budaeva 2007, Tazioli et al. 2007). We have not found any records of antipatharian-associated fauna in the northwestern Gulf of Mexico. We here present records, depths and species associations of a cirripede and three decapod crustaceans that associate with black corals.

\section{Methods}

MN collected specimens in the vicinity of the East and West Flower Garden Banks, Horseshoe Bank, 29-Fathom Bank, Rankin Bank, 28-Fathom Bank, Bright Bank, and Geyer Bank at depths ranging from 68.0 to 123.9 in 2011-2012 (Table 1). Figure 1 shows the natural habitat. Specimens were retrieved using a single function manipulator on a Phantom S2 remotely operated vehicle (ROV). When associated fauna were found, they were removed carefully from the black coral, photographed, and placed in separate containers with $95 \%$ ethanol. The photographs of the freshly collected shrimps are not sufficiently detailed for publication, but a photograph of Uroptychus sp., although the specimen was broken, is of sufficient detail to show the living color pattern.

Antipatharian samples were identified using traditional morphological techniques (corallum branching mode, subpinnule branching patterns, spine morphology and size, and polyp size and distribution). Tissue was removed from a small section of each colony using a 50/50 sodium hypochlorite water solution and an ultrasonic cleaner, dried, and coated with gold-palladium using a sputter coater $(70 \mathrm{~mm}$ target distance, $30 \mathrm{~mA}, 30$ secs) to obtain scanning electron micrographs using a Hitachi TM3000 tabletop scanning electron microscope for analysis of skeletal morphology. MN identified specimens, with problematic species identifications confirmed by black coral taxonomist Dennis Opresko, Research Associate, United States National Museum of Natural History. Antipatharians recently have undergone taxonomic revision (Opresko 1972, 1974, 2001, 2004; Perez et al. 2005). We used currently accepted names when we were sure of the identification. Taxonomic confusion remains regarding the differences (if any) between Antipathes atlantica Gray and A. gracilis Gray, hence in our records we record these species as Antipathes atlanticalgracilis. See Nuttall (2013) for further information on methods and the scope of the projects involved during collection.

Records of the material examined are given in Table 1. Host antipatharians species are not reported for many of the shrimps because they were loose from their hosts after 
Table I. Material examined

\begin{tabular}{|c|c|c|c|}
\hline Coordinates & Collection number & Depth, date & Number, host \\
\hline \multicolumn{4}{|l|}{ Oxynaspis gracilis: } \\
\hline \multicolumn{4}{|c|}{ East Flower Garden Bank: } \\
\hline $27^{\circ} 57.2^{\prime} \mathrm{N}, 93^{\circ} 36.0^{\prime} \mathrm{W}$ & DFH8-19A14, TCWC 2-8958 & 60 m, 3 Sept. 2004 & 2, on Antipathes atlanticalgracilis \\
\hline $27^{\circ} 57^{\prime} \mathrm{N}, 93^{\circ} 36^{\prime} \mathrm{W}$ & DFH11-3A, TCWC 2-9121 & 99 m, 13 Sept. 2005 & 3, on "Antipathes sp." \\
\hline \multicolumn{4}{|c|}{ West Flower Garden Bank: } \\
\hline $27^{\circ} 51.2^{\prime} \mathrm{N}, 93^{\circ} 49.2^{\prime} \mathrm{W}$ & DFH17-17C, TCWC 2-3663 & $82.4 \mathrm{~m}, 1$ Aug. 2012 & 1, on Phanopathes expansa \\
\hline $27^{\circ} 53.9^{\prime} \mathrm{N}, 93^{\circ} 47.0^{\prime} \mathrm{W}$ & DFH17-25B, TCWC 2-3665 & 97 m, 1 Aug. 2012 & 1, on Elatopathes abientina \\
\hline $27^{\circ} 56.8^{\prime} \mathrm{N}, 93^{\circ} 37.4^{\prime} \mathrm{W}$ & DFH17-30C, TCWC 2-3666 & 87.8 m, 2 Aug. 2012 & 1, on Antipathes atlanticalgracilis \\
\hline $27^{\circ} 53.9^{\prime} \mathrm{N}, 93^{\circ} 27.0 \mathrm{~W}$ & PSBF2-18B, TCWC 2-3695 & 116.4 m, 22 Sept. 2012 & 2, on Acanthopathes thyoides \\
\hline $27^{\circ} 51.1^{\prime} \mathrm{N}, 93^{\circ} 26.3^{\prime} \mathrm{W}$ & PSBF2-19B, TCWC 2-3696 & 115.5 m, 22 Sept. 2012 & 2, on Acanthopathes thyoides \\
\hline $27^{\circ} 53.8^{\prime} \mathrm{N}, 93^{\circ} 19.6^{\prime} \mathrm{W}$ & PSBF3-2D, TCWC 2-3668 & 86.2 m, 26 Sept. 2012 & 1, on Tanacetipathes barbadensis \\
\hline $27^{\circ} 53.4^{\prime} \mathrm{N}, 93^{\circ} 15.6^{\prime} \mathrm{W}$ & PSBF3-4B, TCWC 2-3669 & 123.9 m, 26 Sept. 2012 & 1, on Antipathes furcata \\
\hline $27^{\circ} 52.2^{\prime} \mathrm{N}, 93^{\circ} 17.6^{\prime} \mathrm{W}$ & PSBF3-8B, not catalogued & $89.1 \mathrm{~m}, 27$ Sept. 2012 & $\begin{array}{l}\text { 15, on Antipathes atlantical } \\
\text { gracilis }\end{array}$ \\
\hline $27^{\circ} 50.6^{\prime} \mathrm{N}, 93^{\circ} 3.6^{\prime} \mathrm{W}$ & PSBF3-12B, not catalogued & 90.7 m, 28 Sept. 2012 & $\begin{array}{l}\text { 2, on Antipathes atlantical } \\
\text { gracilis }\end{array}$ \\
\hline $27^{\circ} 50.3^{\prime} \mathrm{N}, 93^{\circ} 3.7^{\prime} \mathrm{W}$ & PSBF3-16B, TCWC 2-3698 & 86.2 m, 28 Sept. 2012 & $\begin{array}{l}\text { 4, on Antipathes atlantical } \\
\text { gracilis }\end{array}$ \\
\hline \multicolumn{4}{|l|}{ Horseshoe Bank: } \\
\hline $27^{\circ} 49.9^{\prime} \mathrm{N}, 93^{\circ} 3.37^{\prime} \mathrm{W}$ & \begin{tabular}{|l|} 
PSBF3-17B, donated to \\
California Academy of Sciences
\end{tabular} & 87.8 m, 28 Sept. 2012 & $\begin{array}{l}\text { 2, on Antipathes atlantical } \\
\text { gracilis }\end{array}$ \\
\hline $27^{\circ} 48.8^{\prime} \mathrm{N}, 93^{\circ} 41.5^{\prime} \mathrm{W}$ & PSBF1-3B, TCWC 2-2-3694 & 112.5 m, 24 Oct. 2011 & 4, on Phanopathes expansa \\
\hline $27^{\circ} 52.4^{\prime} \mathrm{N}, 93^{\circ} 42.3^{\prime} \mathrm{W}$ & PSBF3-10B, TCWC 2-3697 & $106.1 \mathrm{~m}, 25$ Oct. 2011 & 2, on Phanopathes expansa \\
\hline \multicolumn{4}{|l|}{ 29-Fathom Bank: } \\
\hline $28^{\circ} 7.7^{\prime} \mathrm{N}, 93^{\circ} 28.9^{\prime} \mathrm{W}$ & PSBF1-13C, TCWC 2-3667 & Oct. 2011 & $\begin{array}{l}\text { 1, on Antipathes atlantical } \\
\text { gracilis }\end{array}$ \\
\hline \multicolumn{4}{|l|}{ Uroptychus sp.: } \\
\hline \multicolumn{4}{|c|}{ West Flower Garden Bank: } \\
\hline $27^{\circ} 51.5^{\prime} \mathrm{N}, 93^{\circ} 49.7^{\prime} \mathrm{W}$ & $\begin{array}{l}\text { DFH17-15B, TCWC 2-3636, } \\
\text { one donated to U.S. National } \\
\text { Museum }\end{array}$ & 78.5 m, 1 Aug. 2012 & 2, on Tanacetipathes thamnea \\
\hline $27^{\circ} 51.3^{\prime} \mathrm{N}, 93^{\circ} 49.6^{\prime} \mathrm{W}$ & DFH17-16E, TCWC 2-3657 & 81 m, 1 Aug. 2012 & 1, on Tanacetipathes tanacetum \\
\hline $27^{\circ} 50.1^{\prime} \mathrm{N}, 93^{\circ} 51.3^{\prime} \mathrm{W}$ & DFH17-22B, TCWC 2-3658 & 120.3 m, 1 Aug. 2012 & 1, on Acanthopathes thyoides \\
\hline \multicolumn{4}{|l|}{ Rankin Bank: } \\
\hline $27^{\circ} 55.2^{\prime} \mathrm{N}, 93^{\circ} 24.8^{\prime} \mathrm{W}$ & $\begin{array}{l}\text { PSBF2-3C, sent to Kumamoto } \\
\text { University }\end{array}$ & 89.3 m, 11 Sept. 2012 & 2, on Tanacetipathes cf. paula \\
\hline \multicolumn{4}{|c|}{ Periclimenes cf. antipathophilus: } \\
\hline \multicolumn{4}{|c|}{ West Flower Garden Bank: } \\
\hline $27^{\circ} 50.9^{\prime} \mathrm{N}, 93^{\circ} 48.1^{\prime} \mathrm{W}$ & DFH17-20C, TCWC 2-3646 & 112.8 m., 1 Aug. 2012 & 1, on Acanthopathes thyoides \\
\hline \multicolumn{4}{|c|}{ Pseudopontonides principis: } \\
\hline \multicolumn{4}{|c|}{ West Flower Garden Bank: } \\
\hline $27^{\circ} 51.5^{\prime} \mathrm{N}, 93^{\circ} 49.7^{\prime} \mathrm{W}$ & DFH17-15C, TCWC 2-3648 & 78.5 m. 1 Aug. 2012 & 1, on Tanacetipathes thamnea \\
\hline $27^{\circ} 51.3^{\prime} \mathrm{N}, 93^{\circ} 49.6^{\prime} \mathrm{W}$ & DFH17-16B, TCWC 2-3649 & 81 m, 1 Aug. 2012 & 1, on Tanacetipathes tanacetum \\
\hline $\begin{array}{l}27^{\circ} 51.3^{\prime} \mathrm{N}, 93^{\circ} 49.6^{\prime} \mathrm{W} \\
27^{\circ} 51.2^{\prime} \mathrm{N}, 93^{\circ} 49.2^{\prime} \mathrm{W}\end{array}$ & $\begin{array}{l}\text { DFH 17-16C, TCWC 2-3654 } \\
\text { DFH 17-17B, TCWC 2-3650 }\end{array}$ & $\begin{array}{l}81 \mathrm{~m}, 1 \text { Aug. } 2012 \\
82.4 \mathrm{~m}, 1 \text { Aug. } 2012\end{array}$ & $\begin{array}{l}\text { 1, on Tanacetipathes tanacetum } \\
\text { 1, on Phanopathes expansa }\end{array}$ \\
\hline
\end{tabular}




\begin{tabular}{l|l|l|l}
\hline Coordinates & Collection number & Depth, date & Number, host \\
\hline East Flower Garden Bank: & \multicolumn{3}{l}{} \\
\hline $27^{\circ} 53.3^{\prime} \mathrm{N}, 93^{\circ} 36.8^{\prime} \mathrm{W}$ & DFH17-33D, TCWC 2-3651 & $90.9 \mathrm{~m}$. 2 Aug. 2012 & 4, on Tanacetipathes thamnea \\
\hline $27^{\circ} 53.3^{\prime} \mathrm{N}, 93^{\circ} 36.8^{\prime} \mathrm{W}$ & DFH17-33C, TCWC 2-3662 & $90.9 \mathrm{~m}, 2$ Aug. 2012 & 1, on Tanacetipathes thamnea \\
\hline Bright Bank: & $86.2 \mathrm{~m}, 26$ Sept. 2012 & 1, on Tanacetipathes tanacetum \\
\hline $27^{\circ} 53.8^{\prime} \mathrm{N}, 93^{\circ} 19.6^{\prime} \mathrm{W}$ & PSBF3-2C, TCWC 2-3653 & \\
\hline Rankin Bank: & $89.3 \mathrm{~m}, 19$ Sept. 2012 & 1, on Tanacetipathes cf. paula \\
\hline $27^{\circ} 55.2^{\prime} \mathrm{N}, 93^{\circ} 24.8^{\prime} \mathrm{W}$ & PSBF2-3C, TCWC 2-3655 &
\end{tabular}

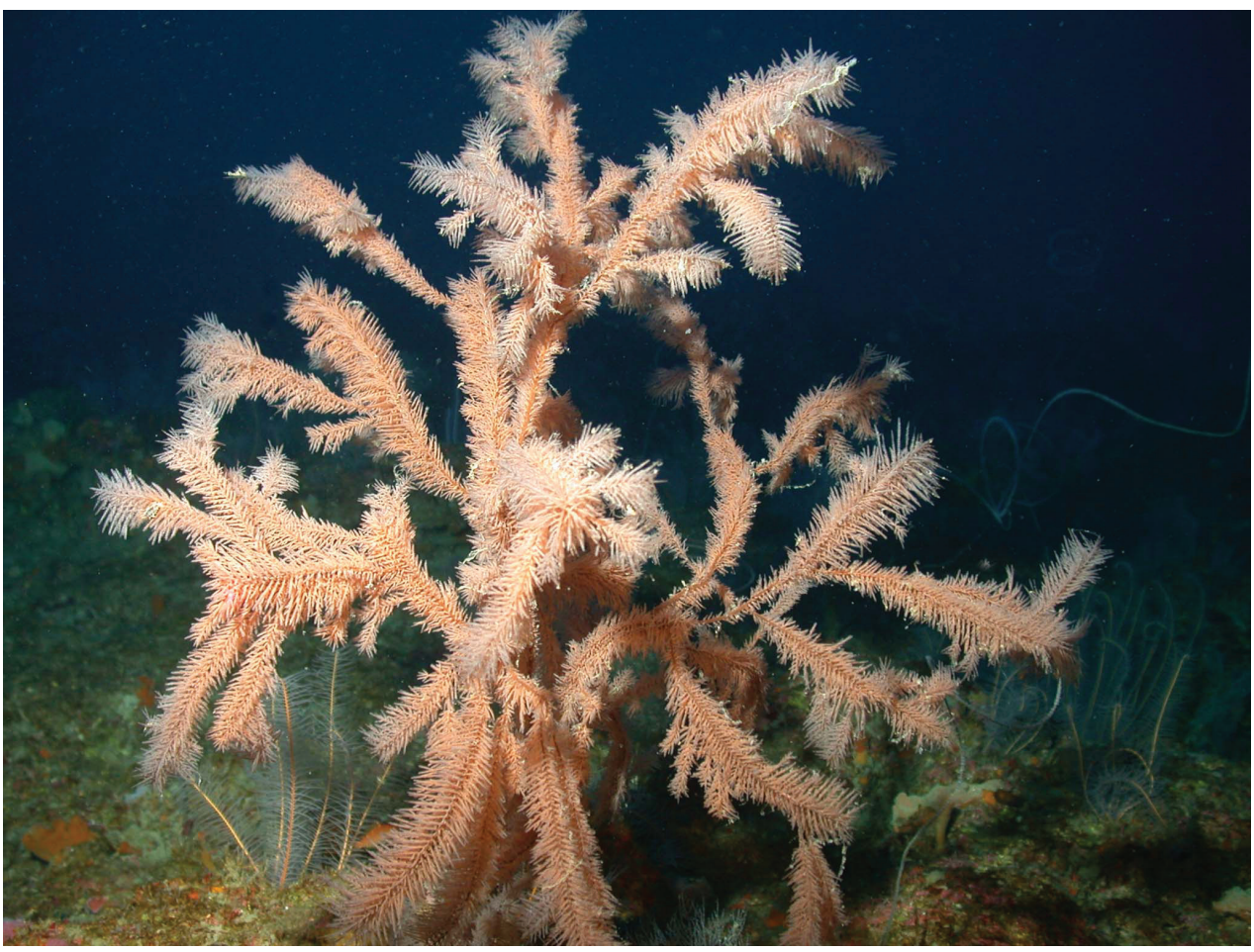

Figure I. Deep reef habitat showing antipatharians Tanacetipathes sp. (foreground) and Stichopathes sp. (distant) among protruding arms of comatulid crinoids (West Flower Garden Bank, 80 m).

collection. Because the two species are considered to be obligate associates of antipatharians, we are confident that they were living on antipatharians before collection. MW identified the carideans and most of the cirripedes. Stephen Gittings, United States National Oceanographic and Atmospheric Administration, identified the specimens of Oxynaspis gracilis Totten from DFH8-19A14.

Except as noted, the specimens were incorporated into the Biodiversity Research and Teaching Collection at Texas A\&M University (formerly the Texas Cooperative Wildlife Collection, TCWC). A few specimens do not have catalog numbers because they are being used for further study. Two specimens of Uroptychus sp. were sent to Keiji Baba, Kumamoto University, Japan, for identification, and another specimen was 
donated to the collections of the U.S. National Museum of Natural History. Although originally thought to belong to Uroptychus minutus Benedict, 1902, these specimens now are considered to represent an undescribed species. Two specimens of Oxynaspis gracilis were donated to the California Academy of Sciences. The collections were part of the Deep Fish Habitat (DFH) and Potentially Sensitive Biological Features (PSBF) studies of the Flower Gardens Banks National Marine Sanctuary collected under permit number FGBNMS-2009-001.

\section{Results}

Oxynaspis gracilis, the black coral barnacle (Cirripedia, Lepadomorpha, Oxynaspididae) is a small (2-5 mm in total length), stalked species found attached to the axes of the corals. It was found on six species, including bottlebrush and fan-shaped species, at 68.0 to 123.9 $\mathrm{m}$. The living tissue of the coral host may encrust the cirriped (Figure 2). This barnacle was collected previously at the East Flower Garden Bank (Table 1). Humann and DeLoach (2002) reported O. gracilis as "occasional Caribbean" on P. pennacea (Pallas) (as A. pennacea) and A. salix Pourtalés. (P.A. McLaughlin, Western Washington University verified the identification of the cirripeds in their photograph). Gittings et al. (1986) did not report this species from the northern Gulf of Mexico in their guidebook, nor is it listed in the master crustacean species list for the United States and Canada (McLaughlin et al. 2005).

Uroptychus sp. (Decapoda, Anomura, Chirostylidae) was found clinging to the main axes of Tanacetipathes spp. and the "sea fan" antipatharian Acanthopathes thyoides, (Pourtalés) at 78.5-120.3 m. Photographs of a freshly collected individual show that the cephalothorax was red, and the chelipeds translucent with a red lateral stripe on the propodus and carpus and red spots on the palm of the chela (Figure 3). An as yet unidentified specimen of Uroptychus sp. from southwestern Florida has a similar color pattern (D. Felder, pers. comm.)

Two shrimps (Decapoda, Caridea, Palaemonidae) were found on the antipatharians. Pseudopontonides principis (Criales), the wire coral shrimp, previously has been reported from the northeastern Gulf of Mexico and Curacao, Bonaire, and Puerto Rico in the Caribbean (Heard 1986, Humann and DeLoach 2002) on Stichopathes leutkeni (Brook) (as Cirrhipathes leutkeni), A. gracilis, P. pennacea, and Virgularia sp. (Pennatulacea). In the northwestern Gulf of Mexico, it has been found on Tanacetipathes spp. and Phanopathes expansa (Opresko and Cairns 1992).

The other caridean, found on Acanthopathes thyoides, is broken and cannot be identified definitely to species. The form of the pereopods, first antennae and rostrum are consistent with Periclimenes antipathophilus Spotte, Heard \& Bubucis, 1994, the black coral shrimp. A photograph of our freshly collected specimen has the same color pattern as that photographed by Humann and DeLoach (2002). This species has been reported in the Bahamas, Turks and Caicos Islands, and eastern Honduras in the Caribbean on Stichopathes gracilis and Stichopathes sp. (as Cirrhipathes sp). It also is common at Bonaire, Netherlands Antilles (R. Heard, pers. comm.) 


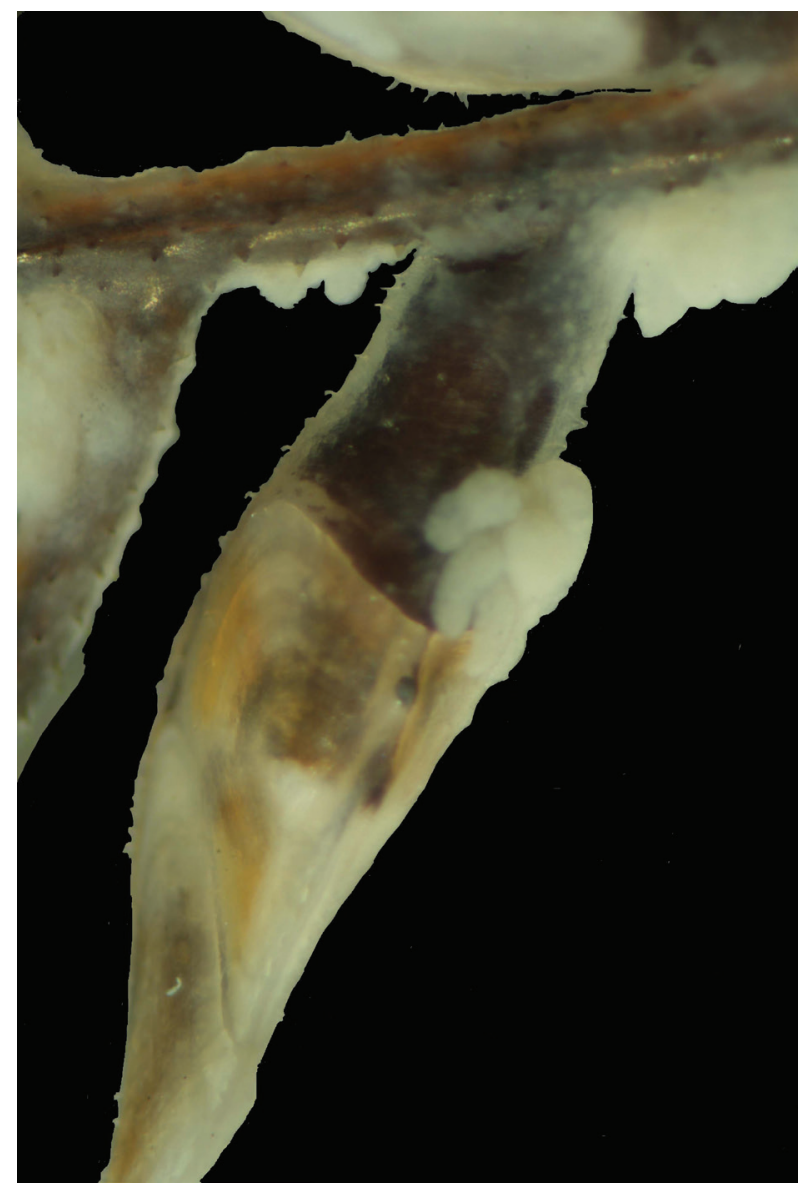

Figure 2. Antipathes atlanticalgracilis overgrowing Oxynaspis gracilis. (Horseshoe Bank, $112 \mathrm{~m}$, sta. PSBF1-3B).

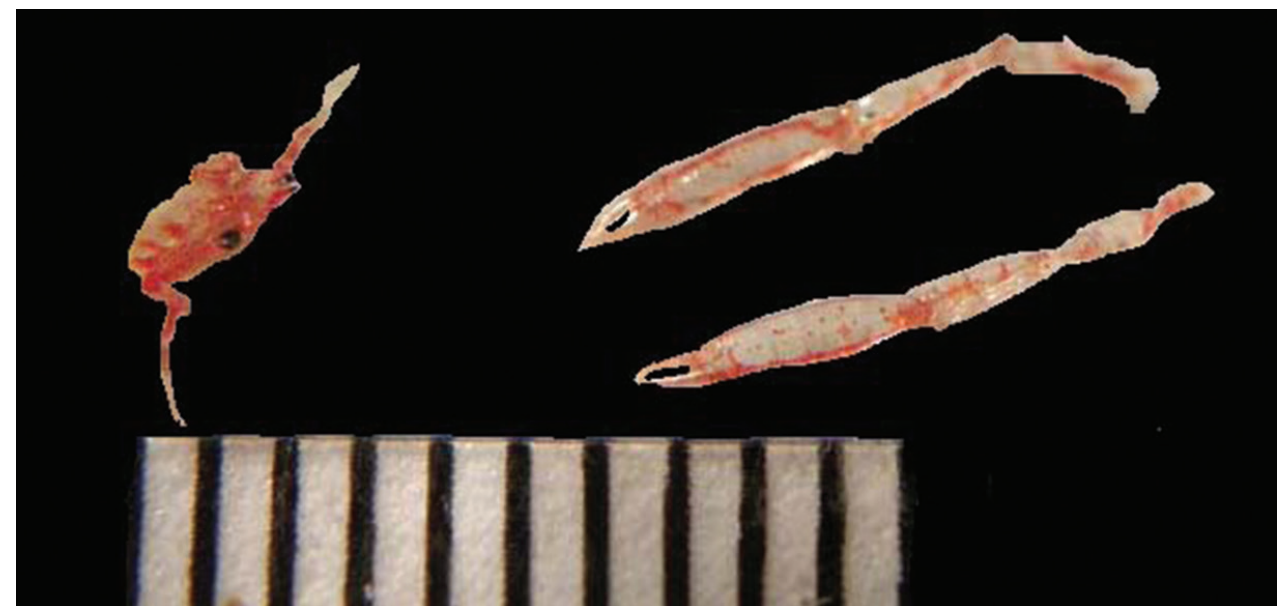

Figure 3. Uroptychus sp., freshly caught (West Flower Garden Bank, 79 m). Scale in mm. 
Also found on the antipatharians was the wing oyster Pteria colymbus (Röding). The wing oyster commonly occurs on gorgonians, antipatharians, or other invertebrates that project upward from the surface of reefs and is not considered to be a strict associate of antipatharians.

Multiple species of associated fauna were documented on a single black coral host. Both U. minutus and Pseudopontonides principis were found on the bottle brush shaped antipatharians Tanacetipathes sp. Both $P$. principis and O. gracilis lived on sea fan antipatharian P. expansa.

\section{Discussion}

Wirtz and d'Udekem-d'Acoz (2001) collected seven species of decapods from antipatharians and gorgonians at the Cape Verde Islands, none of them the same species as found in the Gulf of Mexico. These collections were made by SCUBA diving at depths of 15-30 m, considerably shallow in comparison to our collections. Of the seven species, three were found only on antipatharians, and one shrimp, Periclimenes wirtzi d'Udekem d'Acoz might be an obligate associate of antipatharians. Previous reports of $P$. antipathophilus indicate that it, too, is only found on antipatharians. The authors reported that one shrimp, Pseudocoutierea wirtzi d'Udekem d'Acoz lived in groups of "many individuals" on gorgonians, but only solitary shrimp of this species were found on antipatharians. Because our specimens were collected by ROV, we cannot be sure if Pseudopontonides principis occurred in "groups" but one sample contained four individuals. Two or three individuals of $P$. principis, sometimes of different color patterns, have been photographed on antipatharians in the Caribbean (L. Wilk, pers.comm.). The cirripede occurred singly or in clusters of as many as 15 individuals.

To collect and observe the minute associated crustaceans of colonial cnidarians, one cannot use trawls or dredges. The smaller specimens slip through the mesh or are smashed and unrecognizable. Although the Phantom S2 is equipped with both video and still cameras, it cannot approach a black coral closely enough to see the tiny associated crustaceans. Additionally, the inability to document these interactions in situ makes defining the nature of the relationships between the associated fauna and the host difficult to determine. Although the presence of associated fauna has been documented to alter corallum or spinal morphology of the black coral host (Molodtsova and Budaeva 2007), the host fauna in this study appeared healthy and unmodified, with the exception of black coral overgrowth of $O$. gracilis.

The majority of antipatharians in the northern Gulf of Mexico live in mesophotic or deep-sea environments, beyond the depth range of conventional SCUBA diving. Data from previous collections of antipatharians suggest that they inhabit many banks in the northern Gulf of Mexico. With proper collecting technique, it is likely that investigators will find additional specimens of the associated crustaceans and perhaps additional species. 


\section{Acknowledgments}

We thank Richard Heard, Gulf Coast Research Laboratory, for sharing information on $P$. antipathophilus, Les Wilk, ReefNet Inc., Mississauga, Canada, for sharing photographs of Pseudopontonides principis, and Darryl Felder, University of Louisiana at Lafayette, for sharing his records of Uroptychus sp. Larry Griffing, Texas A\&M University, took the photograph used in Figure 2; and Texas A\&M University at Galveston allowed the use of the scanning electron microscope. Research partners that assisted in the collection of these samples included the University of North Carolina at Wilmington Undersea Vehicle Program (UNCW UVP) and the Louisiana Universities Marine Consortium (LUMCON). The study was funded in part by the National Oceanographic and Atmospheric Administration Deep Sea Coral Research and Technology Program (DSCRTP), the United States Department of the Interior Bureau of Ocean Energy Management (BOEM), and a mini-grant from the Department of Marine Biology, Texas A\&M University at Galveston; and an Erma Lee and Luke Mooney Graduate Student Travel Grant.

\section{References}

Benedict J (1902) Descriptions of a new genus and 46 new species of crustaceans of the family Galatheidae, with a list of the known marine species. Proceedings of the United States National Museum 26: 243-344. doi: 10.5479/si.00963801.26-1311.243

Boland G (2005) Observations of the antipatharian "black coral" Plumapathes pennacea (Pallas, 1766) (Cnidaria: Anthozoa), northwestern Gulf of Mexico. Gulf of Mexico Science 23: $127-132$.

Castro P, Ng P, Ahyong S (2004) Phylogeny and systematics of the Trapeziidae Miers, 1886 (Crustacea : Brachyura), with the description of a new family. Zootaxa 643: 1-70.

Gittings S, Dennis G, Harry H (1986) Annotated guide to the barnacles of the northern Gulf of Mexico. Texas A\&M University Sea Grant Program 86-401: 1-36.

Glasby C (1994) A new genus and species of polychaete, Bollandia antipathicola (Nereidoidea, Syllidae), from black coral. Proceedings of the Biological Society of Washington 107: 615-621. Grange K (1991) Mutualism between the antipatharian Antipathes fiordensis and the ophiuroid Astrobrachion constrictum in New Zealand fjords. Hydrobiologia 216-217: 297-303. doi: 10.1007/BF00026478

Heard R (1986) Pontoniine shrimps (Decapoda: Caridea: Palaemonidae) of the northwest Atlantic. I. The genus Neopontonides Holthuis, 1951, with the description of N. chacei new species, and the erection of Pseudopontonides, new genus, to receive $N$. principis Criales, 1980. Journal of Crustacean Biology 6: 471-484. doi: 10.2307/1548186

Humann P, DeLoach N (2002) Reef Creature Identification: Florida, Caribbean, Bahamas. New World Publications, Jacksonville, Florida. $2^{\text {nd }}$ ed., 420 pp.

Humes A (1990) Sabelliphilid copepods (Poecilostomatoida) associated with cnidarians in the Philippines. Bulletin of Marine Science 47: 581-597. 
McLaughlin P, Camp K (2005) Common and scientific names of aquatic invertebrates from the United States and Canada: Crustaceans. American Fisheries Society Special Publication 31: $1-545$.

Molodtsova T, Budaeva N (2007) Modifications of corallum morphology in black corals as an effect of associated fauna. Bulletin of Marine Science 81: 469-480.

Nuttall M (2013) Antipatharian diversity and habitat suitability mapping in the mesophotic zone of the Northwestern Gulf of Mexico. MS Thesis, Texas A\&M University at Galveston, Galveston, Texas, USA.

Opresko D (1972) Biological results of the University of Miami Deep-Sea Expeditions. 97. Redescriptions and reevaluations of the antipatharians described by LF de Pourtales. Bulletin of Marine Science 22: 950-1017.

Opresko D (1974) A study of the classification of the Antipatharia (Coelenterata: Anthozoa), with redescriptions of eleven species. PhD thesis, University of Miami, Miami, USA.

Opresko D (2001) Revision of the Antipatharia (Cnidaria: Anthozoa). Part I. Establishment of a new family, Myriopathidae. Zoologische Mededelingen Uitgegeven door het Rijksmuseum van Natuurlijke Historie te Leiden 75: 343-370.

Opresko D (2004) Revision of the Antipatharia (Cnidaria: Anthozoa). Part IV. Establishment of a new family, Aphanipathidae. Zoologische Mededelingen Uitgegeven door het Rijksmuseum van Natuurlijke Histoire te Leiden 78: 209-240.

Opresko D, Cairns S (1992) New species of black coral (Cnidaria: Antipatharia) from the northern Gulf of Mexico. Northeast Gulf Science 12: 93-97.

Perez C, Costa D, Opresko D (2005) A new species of Tanacetipathes from Brazil, with a redescription of the type species T. tanacetum (Pourtales) (Cnidaria, Anthozoa, Antipatharia). Zootaxa 890: 1-12.

Pettibone M (1991) Polynoid polychaetes commensal with antipatharian corals. Proceedings of the Biological Society of Washington 104: 714-726.

Spotte S, Heard R, Bubucis P (1994) Pontoniine shrimps (Decapoda: Caridea: Palaemonidae) of the northwest Atlantic. IV. Periclimenes antipathophilus new species, a black coral associate from the Turks and Caicos Islands and eastern Honduras. Bulletin of Marine Science 55: 212-227.

Tazioli S, Bo M, Boyer M, Rotinsulu H, Bavestrello G (2007) Ecology of some common antipatharians from the marine park of Bunaken (North Sulawesi, Indonesia). Zoological Studies 46: 227-241.

Totton A (1923) "Antipatharia" (and their cirripede commensals). In: British Antarctic "Terra Nova” expedition, 1910. Natural History Report. Zoology V, 3. Coelenterata III. British Museum (Natural History), London, 97-119.

Warner G (1981) Species descriptions and ecological observations of black corals (Antipatharia) from Trinidad. Bulletin of Marine Science 31: 147-163.

Wirtz P, d'Udekem-d'Acoz C (2001) Decapoda from Antipatharia, Gorgonaria and Bivalvia at the Cape Verde islands. Helgoland Marine Research 55: 112-115. doi: 10.1007/s101520100073 